WHC-EP-0356

Revision 1

\title{
Single-Shell Tank System Waste Analysis Plan
}

C. H. Mulkey

Date Published

September 1996

Prepared for the U.S. Department of Energy Assistant Secretary for Environmental Management

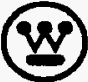

Management and Operations Contractor for the

U.S. Depertment of Energy under Contract DE-AC06-87RL10930

Approved for public release; distribution is unlimited 


\section{RELEASE AUTHORIZATION}

Document Number: WHC-EP-0356, Rev. 1

Document Title: $\quad$ Single-Shell Tank System Waste Analys is Plan

Release Date: $\quad 9 / 19 / 96$

This document was reviewed following the procedures described in WHC-CM-3-4 and is:

APPROVED FOR PUBLIC RELEASE

WHC Information Release Administration Specialist:

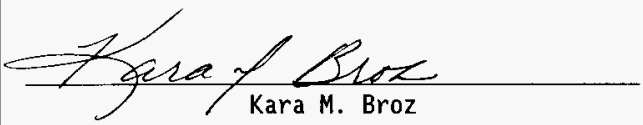




\section{APPROVAL PAGE}

Document Title: SINGLE-SHELL TANK WASTE ANALYSIS PLAN

Prepared by:

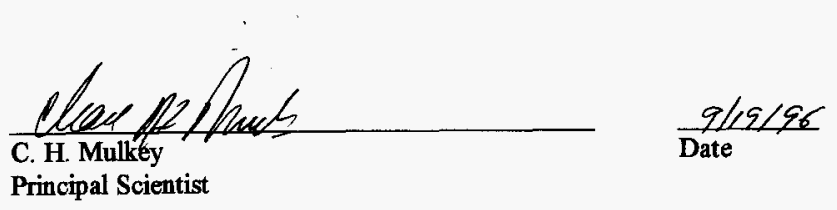

Reviewed by:

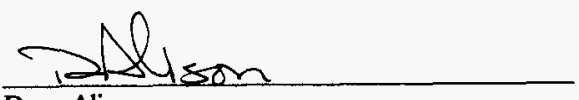

Dann Alison

Manager of TWRS Environmental Compliance and Support Services

Approved by:

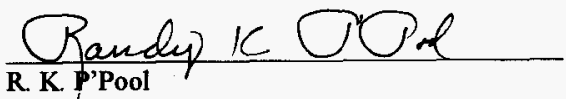

East Tank Farms Environmental Compliance Officer

\section{$\frac{9 / 19 / 96}{\text { Date }}$}

$9 / 19 / 96$

Date

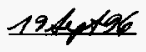

Date

West Tank Farms Environmental Compliance Officer

$\frac{9 / 19 / 96}{\text { Date }}$

Approved by:

Tot adamo

W.L. Adams

Quality Assurance 


\section{CONTENTS}

INTRODUCTION

PURPOSE

SCOPE

1.0 FACILITY DESCRIPTION . . . . . . . . . . . . . . . . . . 3

1.1 PROCESS AND ACTIVITIES ............... . . . 3

1.2 IDENTIFICATION/CLASSIFICATION AND QUANTITIES OF

DANGEROUS WASTE MANAGED IN SSTS ............ 4

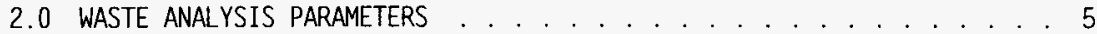

2.1 ANALYSES FOR SAFE STORAGE ............... 5

2.2 ANALYSES NECESSARY FOR WASTE ACCEPTANCE . . . . . . . . . 5

2.3 REGULATORY REQUIREMENTS . . . . . . . . . . . . . . . . 5

2.4 CLOSURE ACTIVITIES . . . . . . . . . . . . . . . . . . . . 6

3.0 SELECTION OF SAMPLING PROCEDURES . . . . . . . . . . . . . . . 7

3.1 SAMPLING STRATEGIES . . . . . . . . . . . . . . . . . . 7

3.2 SELECTION OF SAMPLING EQUIPMENT . . . . . . . . . . . . . . . 7

3.3 MAINTAINING AND DECONTAMINATING FIELD EQUIPMENT . . . . . . . . . 8

3.4 SAMPLE PRESERVATION AND STORAGE . . . . . . . . . . . . . 8

3.5 QUALITY ASSURANCE/QUALITY CONTROL PROCEDURES . . . . . . . . . . . 8

3.6 HEALTH AND SAFETY PROTOCOLS . . . . . . . . . . . . . . . . . . . . 9

4.0 LABORATORY SELECTION AND TESTING AND ANALYTICAL METHODS . . . . . . . 11 4.1 LABORATORY SELECTION . . . . . . . . . . . . . . . . . 11

4.2 TESTING AND ANALYTICAL METHODS . . . . . . . . . . . . . . . 11

5.0 WASTE VERIFICATION . . . . . . . . . . . . . 15

6.0 SPECIAL REQUIREMENTS . . . . . . . . . . . . . 17

6.1 REACTIVE AND IGNITABLE WASTE . . . . . . . . . . . . . . . . . 17

6.2 PROVISIONS FOR COMPLYING WITH LDR REQUIREMENTS . . . . . . . . . . 17

6.3 DEVIATIONS FROM THE REQUIREMENTS OF THIS WASTE ANALYSIS PLAN . . 18

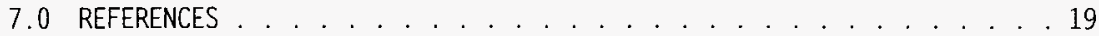


WHC-EP-0356, Rev. 1

\section{ACRONYMS}

CFR

Code of Federal Regulations

DOE

U.S. Department of Energy

DQO

Data Quality Objective

DSC

Differential scanning Calorimeter

DST

Double-shell tanks

Ecology

Washington State Department of Ecology

EPA

U.S. Environmental Protection Agency

HASQAP

Hanford Analytical Services Quality Assurance Plan

LDR

Land disposal restrictions

OSD

Operational specification document

QA

QC

Quality assurance

RCRA

Quality control

SD

Resource Conservation and Recovery Act

SST

TCLP

TGA

Supporting document

Single-shell tank

Toxicity characteristic leaching procedures

TPA

Thermogravimetric analysis

Tri-Party Agreement (Hanford Federal Facility Agreement and Consent Order)

TSAP Tank sampling and analysis plan

TSD

WAC

WAP

Treatment, storage, and disposal

Washington Administrative Code

Waste analysis plan

WHC

WSPS

Westinghouse Hanford Company

Waste stream profile sheet 


\section{DEFINITION OF TERMS}

Certify.

Compatible.

Compatibility 000 .

Engineering.

Ignitable.

Incompatible.

Mixed waste.

Reactive.

Safety Screening DQO.
Attest that information contained in the Waste Profile Sheets and other documentation is true and correct.

Two or more wastes are deemed compatible, if when mixed, they do not (1) generate extreme heat or pressure, fire or explosion, or violent reaction: (2) produce uncontrolled toxic mists, dusts, or gases in sufficient quantities to threaten human health; (3) produce uncontrolled flammable fumes or gases in sufficient quantities to pose a risk of fire or explosions: (4) damage the structural integrity of the device or facility containing the waste; or (5) through other like means threaten human health or the environment, (40 CFR 265.17(b)).

The Data Quality Objectives For Tank Farms Waste Compatibility Program (Fowler 1995a).

The engineering group under Tank Farm Transition Projects or the successors to these groups.

A waste that meets one or more of the criteria of WAC 173-303-090(5)

Wastes that do not meet the above definition of compatible waste are considered incompatible.

A dangerous, extremely hazardous, or acutely hazardous waste that contains both a nonradioactive hazardous component and, as defined by 10 CFR 20.3, source, special nuclear. or by-product material subject to the Atomic Energy Act of 1954 (42 U.S.C. 2011 et seq.). See WAC 173-303-040.

A waste that meets one or more of the criteria of WAC 173-303-090(7)

The latest edition of Tank Safety Screening Data Quality Objectives, which is currently Dukelow et al 1996. 


\section{INTRODUCTION}

The single-shell tank (SST) system stores mixed waste. The current plan is to send the waste to the double-shell tank (DST) system as part of closure activities. The main drivers for waste analysis in SST's are (1) safe storage of the waste, (2) analyses to support waste acceptance into the DST System. (3) meet applicable regulatory requirements and (4)closure issues. Analytes for safe storage and handling issues were derived from Data Quality Objectives for the Waste Compatibijity Program (Fowler 1995a) and the Tank Safety Screening Data Quality Objectives (Dukelow et al 1996). Analyses to meet DST acceptance criteria were taken from the Double-Shell Tank Waste Analysis Plan (Mulkey, Jones 1995). Analyses to meet regulatory requirements are primarily taken from Washington Administrative Code (WAC) 173-303 and Title 40, Parts 264, 265, and 268 of the Code of Federa 7 Regulations (CFR). Analytes to address closure issues are still under development and closure is further addressed in section 2.4. This document does not address the characterization of tanks required by milestone \#44 (M-44) of the Hanford Federal Facility Agreement and Consent Order (TPA) (Ecology et a1. 1996). M-44 was established to address safety issues and dictates a schedule to characterize waste currently in single-shell tanks (SST) and DSTs. Major differences between $M-44$ and this document are that M-44 does not address designation. closure and waste acceptance issues.

\section{PURPOSE}

The primary purpose of this document is to meet the regulatory requirement for a waste analysis plan (WAP) which is required by WAC 173-303 and 40 CFR Part 265. This document can also be used to identify the analyses which are needed to address waste acceptance into the DST System. Generally this regulation requires that (1) measures are taken to ensure that the proper waste has been received and (2) sufficient information is available about the waste to properly manage the waste.

\section{SCOPE}

This WAP applies to dangerous wastes that are transferred out of and/or contained in the SST system. Most of these dangerous wastes are mixed wastes because they also contain radioactive constituents defined by the Atomic Energy Act of 1954. Issues specific to transfers into SSTs are not addressed since addition of waste to the tanks is prohibited by the Wyden Bill (PL 101. 510). 
WHC-EP-0356, Rev. 1

This page intentionally left blank. 
WHC-EP-0356, Rev. 1

\subsection{FACILITY DESCRIPTION}

The Single-She11 Tank (SST) system is a waste management unit within the Hanford Facility. The SST system is operating under interim status pending removal of the tank contents to the DST System and the closure of a11 SSTs. Storage is the principal function of the SST system and waste is no longer added to the tanks for storage. The following sections contain more information on the SSTs but more detailed information can be found in the Single Shell Tank Closure Work Plañ (DOE-RL 1996).

\subsection{PROCESS AND ACTIVITIES}

The SST System consists of 149 tanks which were constructed between 1943 and 1964. These tanks range in size from 55,000 to 1 million gallons (208.000 to 3.8 million liters). These tanks are located in 12 tank farms located in the 200 East and 200 West areas of the Hanford site. All the tanks are constructed below grade and store mixed waste. Descriptions of each tank can be found in the Dangerous Waste Permit Application for the Single Shel1 Tanks (DOE/RL 1993) and in Appendix 2B of RL 1996.

The majority of the waste stored in SSTs was generated by the following chemical processing operations: bismuth phosphate $\left(\mathrm{BiPO}_{4}\right)$ process, the reduction/oxidation (REDOX) process, the plutonium-uranium extraction (PUREX) process, the tributyl phosphate (TBP) process, and the B Plant waste fractionation process. The waste consists of sodium hydroxide: sodium salts of nitrate, nitrite, carbonate. aluminate, and phosphate: and hydrous oxides aluminum, iron, and manganese. The radioactive components consists of fission products such as strontium-90, cesium-137, and iodine-129, and actinides such as uranium. neptunium, plutonium, thorium, and americium. Most of the waste is in the form of sludge, salt cake, and pumpable and nonpumpable liquids.

Waste levels in the tanks remain fairly stable as no new waste is added to the tanks for storage. Levels in the tanks do change due to evaporation and from specific activities such as the removal of pumpable iiquid (supernate) which "interim stabilizes" a tank which reduces the potential for significant leakage. Levels in tank C-106 change when cooling water is added as needed to control the temperature of the waste. Without the cooling water the radio lytic reactions could heat up the tank contents to the point where tank integrity could be compromised. Waste levels may also change during retrieval activities due to the addition of water or other fluid which may be added to facilitate the removal of tank solids. 


\subsection{IDENTIFICATION/CLASSIFICATION AND QUANTITIES OF DANGEROUS WASTE MANAGED IN SSTS}

Washington Administrative Code (WAC) 173-303 requires that all dangerous waste be designated by the waste's generator. The waste in SSTs was not designated when it was produced since it was generated prior to passage of the Resource Conservation and Recovery Act. Waste designation after the fact was accomplished by using available knowledge of the processes and the chemicals which were used in the process. When waste designation occurred, the available analytical data on waste composition was very limited. As result of the limited information which was available and the intermixing of tank contents. the waste was very conservatively designated. This also led to the same waste designation being applied to all tanks even though actual waste composition does vary between the tanks and most tanks do not exhibit the characteristics of ignitability and reactivity. The designations which were placed on the tanks are contained in the Resource Conservation and Recovery Act (RCRA) Dangerous Waste Permit Application (DOE/RL-88-21). 


\subsection{WASTE ANALYSIS PARAMETERS}

Analytical requirements for the SSTs are based on safe storage of the waste. regulatory requirements for the designation of the waste and analyses which are required to transfer the waste to the DST System. These requirements are described in more detail in the following sections. This section provides the selection of analytical parameters based on WAC 173-303-300(5)(a) and the EPA WAP guidance manual (EPA 1994).

\subsection{ANALYSES FOR SAFE STORAGE}

Analyses for safety considerations revolve around issues associated with static storage and those from the transfer of material. Safety related parameters for static storage were identified in the Safety Screening DQO (Dukelow et al 1996). Dukelow et al 1996, provides a method for screening tanks for the safety issues and tanks which fail the screening mechanism are further evaluated against safety issue specific DQOS such as the Organic DQO. If a particular safety concern is identified for a particular tank, the tank is put on a "Watch List" for that safety parameter. Activities involving tanks which are on one or more watch lists are closely scrutinized and controlled to prevent there being any problems associated with the safety concern. Safety issues related to transfers out of the SSTs and into the DST System are addressed by the waste acceptance criteria for the DST System and by the Compatibility DQ0 (Fowler 1995).

\subsection{ANALYSES NECESSARY FOR WASTE ACCEPTANCE}

No analyses are required for waste acceptance into the SST System since it does not receive any new waste. Since the planned disposal of SST waste is through the DST System, some analyses will be needed to meet DST waste acceptance criteria. The analytes were taken from the Double-Shell Tank Waste Analysis Plan (Mulkey, Jones 1995). These analytes ensure that incompatible waste wi11 not be mixed and provide information which is necessary to address operational requirements in addition to safety issues. Analytes which addressed safety issues were developed through the Data Quality Objectives (DQO) process and are contained in the Compatibility DQO (Fowler 1995).

\subsection{REGULATORY REQUIREMENTS}

Many regulatory requirements in state and federal regulations (WAC 173-303-300(2) and (5)(a), WAC 173-303-140, 40 CFR 265.13(a)(1) and (b)(1), and 40 CFR $268.7(\mathrm{a})$ ) require that information on waste in treatment, storage, and disposal (TSD) facilities be obtained, documented, and/or 
reported. As stated in section 1, the waste in the SSTs was designated using process knowledge. Because analytical information was not available, the process knowledge used for designation was supported by very iimited to no actual analytical data. This resulted in the same waste designation being applied throughout the SST System. Currently there was no differentiation of waste designation between tanks. The assumption has been made that the tank waste must be treated to meet land disposal criteria for each of the waste codes which has been placed on the SSTS. The analyses which can be used to confirm waste designation are listed in Table 6-1 of Mulkey 1996.

Waste designation is not only required for the waste in the tanks but for waste which is generated from the different activities supporting the SSTs. This "secondary" waste ranges from contaminated sampling devices to equipment which is removed as part of closure activities.

The waste in the SSTs has been designated as having the characteristics of ignitability and flammability, but do not typically exhibit these characteristics because of the low concentration of ignitable and/or reactive components.

\subsection{CLOSURE ACTIVITIES}

Specific closure activities and schedules have been incorporated into $M-45$ of the TPA and are not covered by this document. 
WHC-EP-0356, Rev. 1

\subsection{SELECTION OF SAMPLING PROCEDURES}

This section contains requirements for the sampling methods and procedures that must be used for analytical requirements specified by this document. Samples not required by this document, such as for waste retrieval studies are considered outside of the scope of this document and do not have to adhere to these requirements. The samples required by this document support safety evaluations and environmental compliance issues. Actual sampling of SSTs will be conducted according to requirements contained in sampling event specific tank sampling analysis plans (TSAPS) or other documents as required by M-44 of the TPA.

\subsection{SAMPLING STRATEGIES}

This document does not specify a sampling strategy which must be used since the Tank Sampling and Analysis Plan (TSAP) which is prepared for each tank will specify the sampling locations for each tank. The selected sampling strategy must ensure that representative samples are taken. There should be check for sampling anomalies by obtaining at least two data points (samples) from each discreet layer of interest. Normally the layers of interest would be supernate for interim stabilization activities and sludge and or salt cake

retrieval purposes. Additional samples should be taken if analytical 1 ...jults from the first sampling event indicate that the samples may not have been representative. This determination can be made in the same manner as the number of samples was determined in the 242-A Evaporator DQ0 (Von Bargen 1995) with the regulatory limits substituting for the operational limits. Normally, there should be an order of magnitude difference between sample results and at least one of the results should be greater than $50 \%$ of a regulatory limit or other decision point, before additional samples are required. If additional samples are indicated, consideration of accessibility limitations should be factored into the decision as the number of access points SSTS is very limited. Section 2.3.1 of EPA's WAP guidance manual (EPA 1994)can be used for guidance when developing the sampling strategy. In this section. EPA has recognized that accessibility is a factor in determining a sampling strategy.

\subsection{SELECTION OF SAMPLING EQUIPMENT}

Sampling equipment selection must consider the physical and chemical properties of the waste and site-specific issues such as accessibility. The selected equipment should be specified in the TSAP. For the purposes of this 
WHC-EP-0356, Rev. 1

document samples can be taken either by the bottle on a string method for liquid samples or through the use of a core type sampler. Alternative sampling devices may be used as long as representative samples are obtained.

\subsection{MAINTAINING AND DECONTAMINATING FIELD EQUIPMENT}

Equipment used to collect and transport samples must be free of contamination that could alter test results. Sampling equipment can be used equipment as long as it has been cleaned to remove any contamination that could alter analytical results. Also, new equipment can be used as long as it does not contain manufacturing or packaging residues that could affect analytical results. After use sampling equipment that has come into contact with the waste, must be either cleaned or sent to an appropriate TSD facility. Equipment maintenance and decontamination methods specified in a pertinent $D Q 0$ or by the Hanford Analytical Services Quality Assurance Plan (HASQAP) must be followed.

\subsection{SAMPLE PRESERVATION AND STORAGE}

Sample preservation must follow those procedures set forth for the specific analysis identified in the appropriate Tank Sampling Analysis Plan (TSAP) or other sampling plan. Because of concerns with radioactivity, preservation may not follow the methods stated in SW-846, but must follow the test methods adopted by the Hanford Site and comply with applicable requirements of WAC 173-303 and requirements specified in pertinent DQOs and the HASQAP.

\subsection{QUALITY ASSURANCE/QUALITY CONTROL PROCEDURES}

The quality assurance/quality control (QA/QC) procedures will vary according to the particular situation. QA/QC requirements for sampling will be divided between paperwork requirements (e.g. chain-of-custody) and sampling and analysis activities. This section addresses sampling $Q A / Q C$ requirements and analytical QA/QC is discussed in Section 4.0. Quality control procedures for tank sampling will be included in the TSAPS.

A chain-of-custody procedure is required for all sampling identified by this WAP. At a minimum, the chain-of-custody must include (1) description of waste collected, (2) printed names and dated signatures of samplers, (3) date and time of collection and number of containers in the sample, and (4) printed names and dated signatures of persons involved in custody of the samples. The chain-of-custody procedure should document custody of the sample from the time of the sampling event through completion of analysis. 
WHC-EP-0356, Rev. 1

QA/QC for sampling consists primarily of checking for contamination through blanks. Establishing quality assurance and quality control procedures are explained in more detail in Section 2.3.5 of EPA 1994. If QA/QC procedures for blanks and duplicates have been specified in either a pertinent DQO, sampling, or analysis plan. then the procedures specified in the $\mathrm{DQ0} / \mathrm{plan}$ must be followed. If requirements for blanks and duplicates have not been specified, then the following requirements should be followed for every sampling event.

1. Check for sampling equipment contamination by taking at least one sample of an equipment rinse per sampling event. This requirement may be waived if new equipment is used and it has been prepared in such a way that it should not contain any contamination.

2. Check for general replicability of results by taking at least one set of field duplicates (i.e. two samples from the same tank) and requiring that the laboratory conduct a duplicate spike on at least one sample. In the event that a duplicate cannot be taken, the the sample should be split and analyzed as if it were two separate samples.

Whenever blanks and/or duplicates are taken, they must be treated as if they are actual samples. This treatment includes, but is not limited to, adding preservatives to the blanks in the same amount as added to the samples, and storing the blanks and duplicates in the same manner as samples.

\subsection{HEALTH AND SAFETY PROTOCOLS}

Health and safety of workers involved in all work to support sampling and analysis cannot and will not be compromised. This will be of primary concern in developing sampling plans. Safety and health protocol requirements are unit-specific and are incorporated into activity specific sampling procedures. One of the key considerations is to keep all exposure as low as reasonably achievable (ALARA). Because each sampling activity may be different, the specific protocols for ALARA and health and safety are not specified in this document; but are included in the sample specific procedures that are written for each sample collection activity. Any specific requirements relating to safety and health protocols that are in pertinent DOOS. WAPS, and TSAPs, must also be followed for all samples required in this document. 
WHC-EP-0356, Rev. 1

This page intentionally left blank. 
WHC-EP-0356, Rev. 1

\subsection{LABORATORY SELECTION AND TESTING AND ANALYTICAL METHODS}

This section provides laboratory selection and the types of acceptable analytical methods.

\subsection{LABORATORY SELECTION}

Laboratory selection is limited as a few laboratories are equipped to handle mixed waste. The preferred laboratory will be one of the laboratories on the Hanford Site, but an offsite laboratory may be used. Laboratory selection will be dependent upon laboratory capability, nature of the sample, timing requirements, and cost. The Analytical Services Program Management and Integration group (or its successor) will select the laboratory. At a minimum the selected laboratory must provide data with sufficient quality to meet the requirements for making decisions described in the applicable DQ0s. The selected laboratory must also comply with the requirements contained in the Hanford Analytical Services Quality Assurance Plan (DOE/RL 1994).

\subsection{TESTING AND ANALYTICAL METHODS}

Testing and analytical methods will be dependent upon the analysis being sought and the reason for needing the information. Analytical methods will be selected from those that are routinely used by the various Hanford Site analytical laboratories. These methods are discussed in Analytical Methods for Mixed Waste Analyses at the Hanford Site (DOE/RL 1994). Analytical methods must meet pertinent regulatory requirements such as those contained in WAC 173-303.

Table 4-1 lists parameters and test methods which must be used to obtain the data for acceptance into the DST system. The analytes. methods, and sensitivity specifications reflect requirements in Fowler 1995. In addition to this list, analyses for the components listed in tables 6.1 and 6.2 of Mulkey 1996 should be conducted on each tank in order to address the regulatory concerns. 
WHC-EP-0356, Rev. 1

Table 4-1. Required Analyses. ${ }^{1}$

\begin{tabular}{|c|c|c|}
\hline 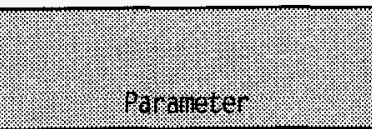 & . thest & 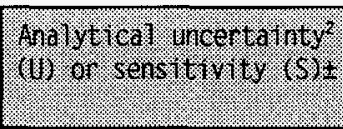 \\
\hline $\begin{array}{l}\text { Energetics (or } \\
\text { Exotherm/endotherm ratio) }\end{array}$ & $\begin{array}{l}\text { Differential scanning } \\
\text { calorimetry supported by } \\
\text { thermo-gravimetric } \\
\text { analysis (TGA) results to } \\
\text { be reported in cal/g and } \\
\text { whether there is a net } \\
\text { exotherm. }\end{array}$ & $\begin{array}{l} \pm 11.5 \mathrm{cal} / \mathrm{g} \text { dry } w \mathrm{t} \\
\text { basis (U) }\end{array}$ \\
\hline Hydroxide & Titration & $0.01 M(5)$ \\
\hline Moisture, \% & $\begin{array}{l}\text { Thermo-gravimetric } \\
\text { analysis }\end{array}$ & $\pm 1.7 \%$ water $(\mathrm{U})$ \\
\hline Nitrate & Ion chromotography & $0.24 \mu \mathrm{g} / \mathrm{ml}(\mathrm{S})$ \\
\hline Nitrite & Ion chromotography & $0.5 \mu \mathrm{g} / \mathrm{ml}(\mathrm{S})$ \\
\hline Organics, separable & Visual & Not specified \\
\hline $\mathrm{pH}$ & Electrode & Not specified \\
\hline $\begin{array}{l}\text { Plutonium- } 239 / 240 \text { or } \\
\text { total alpha }\end{array}$ & $\begin{array}{l}\text { Alpha Energy Analysis, or } \\
\text { total alpha count }\end{array}$ & $10^{-5} \mu \mathrm{ci} / \mathrm{sample}(\mathrm{S})$ \\
\hline Solids, vol \% & Not specified & Not Specified \\
\hline Specific gravity & Gravimetric / Volumetric & Not applicable \\
\hline $\begin{array}{l}\text { Uranium (if the } \\
\text { concentration of } 235 \mathrm{U} \text { is } \\
\text { greater than } 1 \% \text { of the } \\
\text { total uranium content) }\end{array}$ & Not specified & Not Specified \\
\hline Aluminum & $\begin{array}{l}\text { Inductively coupled } \\
\text { plasma (ICP) or atomic } \\
\text { absorpbtion }\end{array}$ & $24 \mu \mathrm{g} / \mathrm{m}\rceil$ (S) \\
\hline Americium 241 & Atomic Energy Analysis & $10^{-5} \mu \mathrm{Ci} / \mathrm{ml} \quad(\mathrm{S})$ \\
\hline Carbonate & $\begin{array}{l}\text { Total organic } \\
\text { carbon/Total inorganic } \\
\text { carbon }\end{array}$ & $5 \mu \mathrm{g} / \mathrm{sample}(\mathrm{S})$ \\
\hline Cesium 137 & beta count & $\left.10^{-5} \mu \mathrm{Ci} / \mathrm{m}\right\rceil(\mathrm{S})$ \\
\hline
\end{tabular}


WHC-EP-0356, Rev. 1

\begin{tabular}{|l|l|l|}
\hline Cyanide $^{3}$ & Not specified & Not Specified \\
\hline Fluoride & $\begin{array}{l}\text { ion chromatography or } \\
\text { inductively coupled } \\
\text { plasma }\end{array}$ & $0.09 \mu \mathrm{g} / \mathrm{ml}(\mathrm{S})$ \\
\hline Phosphate & $\begin{array}{l}\text { ion chromatography or } \\
\text { inductively coupled } \\
\text { plasma }\end{array}$ & $58 \mu \mathrm{g} / \mathrm{ml} \mathrm{(S)}$ \\
\hline Strontium 90 & beta count & $10^{-5} \mu \mathrm{Ci} / \mathrm{ml}(\mathrm{S})$ \\
\hline Sulphate & ion chromotography & $13 \mu \mathrm{g} / \mathrm{mT}(\mathrm{S})$ \\
\hline Total fuel content & Reactive system screening & $480 \mathrm{~J} / \mathrm{g}(\mathrm{S})$ \\
\hline Total Organic Carbon & $\begin{array}{l}\text { Furnace oxidation or } \\
\text { persulfate oxidation }\end{array}$ & $1 \mu \mathrm{g} / \mathrm{ml}(\mathrm{S})$ \\
\hline
\end{tabular}

Note:

'Taken from Table 7-2 and 7-3 of Fowler 1995 and Table 6.2 of Dukelow et al 1996. The sensitivity for hydroxide was updated to reflect revised standards.

${ }^{2}$ These are the expected instrument detection limits and if these limits cannot be met, then the limits specified by the Hanford Analytical Services Quality Assurance Plan (DOE 1995) and the laboratory specific quality control plans must be met. 
WHC-EP-0356, Rev. 1

This page intentionally left blank. 


\subsection{WASTE VERIFICATION}

The one time analysis of the tank contents should be sufficient and no additional verification should be necessary unless either the tank contents change significantly [see WAC 173-303-300(4)(a)]or the analysis which are conducted indicate that a representative sample was not obtained. When waste is transferred, it will need to meet any verification requirements specified by the receiving facility. 
WHC-EP-0356, Rev. 1

This page intentionally left blank. 
WHC-EP-0356, Rev. 1

\subsection{SPECIAL REQUIREMENTS}

The Dangerous Waste regulations (WAC 173-303) contain specific requirements for certain parameters. The following sections address regulatory concerns relating to the characteristics of reactivity and ignitability in addition to land Disposal Requirements.

\subsection{REACTIVE AND IGNITABLE WASTE}

The SST system is permitted to store both reactive and ignitable wastes. Issues relating to reactivity and ignitability are addressed along with other compatibility issues during the compatibility assessment which will be conducted before all transfers into the DST system. The analytes in Dukelow et al 1996 should identify any tanks which actually exhibit either of these properties. If the waste in a tank is found to exhibit the characteristic of reactivity and/or ignitability, it would also fail one of the issue specific safety DQOS and the tank would be placed on the watch List. In order to prevent problems, transfers into DST Watch List tanks are severely restricted.

\subsection{PROVISIONS FOR COMPLYING WITH LDR REQUIREMENTS}

Land disposal restrictions (LDR) are codified in 40 CFR 268 and WAC 173-303-140. These regulations are designed to ensure that Dangerous (hazardous) waste meets specified standards before its disposal to land. The LDR restrictions are placed on a waste when it is generated and are passed on with the waste until such time as the requirements are met. In the DST system, there is no treatment to meet LDR standards. This results in the codes which were placed on the waste when it was generated remaining on the waste while it is in the DST system.

The LDR requirements are tracked by requiring that DST customers identify any LDR requirements that are applicable to their waste streams on the WSPS and on waste transfer information. Because of the DST system's capabilities, there is no treatment or segregation of wastes for LDR concerns and requirements. LDR requirements for waste currently in and for waste transferred to the DST system will be summarized and these requirements will be imposed on the waste transferred out of the DST system.

There is no treatment for LDR requirements in the SST system, and waste in the system is assumed to not meet the LDR requirements for which it was listed. Prior to actual disposal of the waste, compliance with LDR requirements wi 11 have to be met. This is expected to occur in downstream treatment units. The 
analyses identified in Mulkey 1996 can be used to further identify the LDR requirements which should be placed on the waste in each tank.

\subsection{DEVIATIONS FROM THE REQUIREMENTS OF THIS WASTE ANALYSIS PLAN}

In order to address emerging issues, Tank Farm Transition Projects may approve deviations from this WAP after informing the DOE-RL and Ecology unit managers. These deviations must be documented in writing with a copy to be retained in the operating record. 


\subsection{REFERENCES}

40 CFR 264 EPA, 1994, "Standards for Owners and 0perators of Hazardous Waste Treatment, Storage and Disposal Facilities," Code of Federal Regulations, as amended.

40 CFR 265 EPA, 1994. "Interim Status Standards for Owners and Operators of Hazardous Waste Treatment, Storage and Disposal Facilities," Code of Federal Regulations, as amended.

40 CFR 268 EPA, "Land Disposal Restrictions," Code of Federal Regulations, as amended.

DOE-RL, 1993. Hanford Site Annual Dangerous Waste Report, D0/RL-94-10. U.S. Department of Energy/Richland Field Office, Richland, Washington.

DOE, 1994, Hanford Analytical Services Quality Assurance Plan, DOE/RL-94-55. U.S. Department of Energy/Richland Operations, Richland Washington.

DOE-RL, 1994b, Analytical Methods for Mixed Waste Analysis at the Hanford Site, DOE/RL-94-55. U.S. Department of Energy/Richland Operations, Richland, Washington.

D0E-RL, 1996. Single-She 77 Tank Closure Work P7an, DOE/RL-89-16 DOE/RL-94-55. U.S. Department of Energy/Richland Operations, Richland, Washington.

Dukelow, G. T., J. W. Hunt, H. Babad, and J. E. Meacham, 1995, Tank Safety Screening Data Quality Objectives. WHC-SD-WM-SP-004, Rev. 2, Westinghouse Hanford Company, Richland, Washington.

EPA, 1994, Waste Analysis at Facilities That Generate. Treat. Store, and Dispose of Hazardous Wastes, A Guidance Manua 7, PB94-963603, OSWER 9938.4-03, U.S. Environmental Protection Agency, Washington, D.C.

EPA, 1992. Test Methods for Evaluation Solid Waste, SW-846, 3rd Edition, U.S. Environmental Protection Agency, Washington, D.C.

Ecology, EPA, and DOE, 1994. Hanford Federal Facility Agreement and Consent Order, 2 vols.. as amended. Washington State Department of Ecology, U.S. Environmental Protection Agency. U.S. Department of Energy, 01ympia, Washington. 
Fowler, K. D., 1995a, Data Quality Objectives for The Waste Compatibility Program, WHC-SD-WM-DQ0-001, Rev. 1, Westinghouse Hanford Company, Richland, Washington

Fowler, K. D., 1995b. Tank Farm Waste Transfer Compatibility Program. WHC-SD-WM-OCD-015, Rev. 1. Westinghouse Hanford Company, Richland, Washington.

Hyatt, J. E., 1995. Hanford Sampling Quality Management Plan. WHC-SD-WM-PLN-088. Rev. 0 Westinghouse Hanford Company, Richland. Washington.

Mulkey, C.H., 1996. Sampling and Analytical Requirements Relating To Meeting Regulatory Requirements For Dangerous Waste, WHC-SD-WM-DQ0-025, Rev. 0 , Westinghouse Hanford Company, Richland, Washington.

Mulkey. C.H. and J. M. Jones, 1994, Double-Shell Tank Waste Analysis Plan, WHC-SD-WM-EV-053, Rev. 2, Westinghouse Hanford Company, Richland, Washington.

WAC 173-303, 1994, "Dangerous Waste Regulations," Washington Administrative Code, as amended.

WHC, 1995. Tank Farm Summary Report for Month Ending June 30, 1995. WHC-EP-0182-87. Westinghouse Hanford Company, Richland, Washington.

WHC, 1993, Hanford Site Solid Waste Acceptance Criteria, WHC-EP-0063. Rev. 4. Westinghouse Hanford Company, Richland, Washington.

WHC, 1988, Environmental Compliance, WHC-CM-7-5, Release 69, Westinghouse Hanford Company, Richland, Washington.

Wyden Bill, PL 101-510, Section 3137 (1990) 


\section{WHC-EP-3056 REV. 1}

\section{DISTRIBUTION}

Number of Copies

1

1

1

1

1

2

1

1

1

1

1

1

4

6

1

1 .

1

2

2

W. L. Adams

Name

MSIN

D. Alison

S5-13

J. M. Barnett

R1-51

K. E. Be1]

T4-08

T. M. Blaak

R2-12

M. L. Dexter

S5-13

S. J. Eberlein

R1-51

R2 - 12

B. G. Erlandson

R2 - 36

J. D. Guberski

R1-51

M.J. Hall

T5-03

J. W. Hunt

R2 -12

S. J. Lijek

S7 -73

D. J. McCaine

R2 -12

C. H. Mulkey

R1-51

R. K. P'Pool

S5-03

C. 0 . Ruud

S7-54

K. S. Tollefson

S7-01

Central files

A3-88

Document Process Center

A3-94

Distr-1 
THIS PA GF NNTENTIONALLY

I. T. T BLANK 


\section{WHC-EP-3056 REV. 1 \\ DISTRIBUTION}

Number of Copies

1
1
1
1
1
2
1
1
1
1
1
1
4
6
1
1
1
2
2
W. L. Adams

D. Alison

J. M. Barnett

K. E. Bell

T. M. Blaak

M. L. Dexter

S. J. Eberlein

B. G. Erlandson

J. D. Guberski

M.J. Hall

J. W. Hunt

S. J. Lijek

D. J. McCaine

C. H. Mulkey

R. K. P'Pool

C. 0 . Ruud

K. S. Tollefson

Central files

Document Process Center
Name

MSIN

S5-13

R1-51

T4- 08

R2-12

S5-13

R1-51

R2-12

R2-36

$\mathrm{R} 1-51$

T5- 03

R2-12

S7-73

R2-12

R1-51

S5-03

$57-54$

57-01

A3-88

A3-94

Distr-1 
THIS PAGE INTENTIONALLY LEFT BLANK. 